\title{
PERFORMERS AND RESEARCHERS IN NEO-PAGAN SETTINGS
}

\section{KAMILA VELKOBORSKÁ}

In neo-pagan and magical settings, the traditional distinction between the anthropologist and the "others" disappears due to the fact that researchers and performers tend to have the same ethnic background, social position, and level of formal education. Author has identified main approaches towards magic used by anthropologists.

Keywords: neo-pagan, magic, unverified personal gnosis, secrecy, participation, ritual
V novopoganskih in magičnih okoljih ni več tradicionalne razlike med antropologom in "drugimiu, saj imajo raziskovalci in izvajalci pogosto enako etnično ozadje, družbeno pozicijo in stopnjo formalne izobrazbe. Avtorica je izpostavila osnovne antropološke poglede na magijo

Ključne besede: novopogansko, magija, nepreverjeno osebno, spoznanje, tajnost, udeležeba

Seeing magic as delusion is a legacy of the Enlightenment. It is based on the claim that only the physical world is ontologically real and that magic, "the purported art of influencing the course of events through occult means" (Barnard \& Spencer 2002: 340), is characteristic of "primitive" people. The general understanding of magic as delusion lasted until the 1970s and 1980s, when a number of anthropologists began to open up to the phenomenon and to focus on the emic perspective and participation in their research.

Until that time, magical practice was hidden from the sight of the general public. High magic, also called ceremonial magic, belonged to the domain of the elite, whereas low magic, also called witchcraft, was practiced by members of the agricultural populations of the rural areas of Europe. The 1970s and 1980s saw an explosive spread of magical practice among the middle classes in the West. These newly emerging magic-practicing circles of city dwellers constituted a new field for anthropologists, who had to adapt to completely new circumstances.

The first thing the field researcher of contemporary Western magic has to face is the fact that he or she is indistinguishable from his or her field. (see Luhrmann 1989; Evans \& Green 2009) Apart from having the same ethnic and social background, practitioners of magic tend to have a high level of formal education and hold professional jobs (very often in secondary education or university positions or professions connected with information technologies), but they are also very well self-educated in history, religious studies, and anthropology, the researcher's own field. Some have degrees in or are students of anthropology or religious studies. They write articles and books, they organize conferences, participate in symposiums and talks, and so on.

The "others" are traditionally described as the people observed by anthropologists and not really knowing what they are doing. Usually they seem to be more or less blindly 
following a tradition they were born into. In neo-pagan and magical settings, this is not the case. The contemporary Western practitioners of magic know very well what they are doing and why they are doing it. As a result, in a meeting between a beginner anthropologist and an experienced magician, the balance of capacities and knowledge of the subject may lean towards the magician. The informant becomes a consultant and advisor.

Another problem to be faced by an anthropologist trained to become a participant observer is that magic is a mental process and therefore it is invisible. Moreover, magical practice tends to be private and often secret. Privacy, secrecy, and the inner, hidden nature of magic make the phenomenon non-observable by a common anthropologist (there is nothing much the anthropologist may see) even if he or she is lucky enough to be allowed to observe the magical ritual — and that is not very likely. Participant observation-with the emphasis on participation - is the only way to gain relevant data.

The third problem causing the intangibility of magic is the fact that there is very little dogma or no dogma at all surrounding magical practice. The practitioners are familiar with ancient and recent grimoires as well as books written by eminent magicians and anthropologists, and many (but not all) use them in their magical practice. The core of magical practice today, as I have come to know it, lies in so-called UPG, or unverified personal gnosis. UPG is achieved in altered states of consciousness such as meditation, trance, or direct insight. The very nature of UPG makes grasping it from a rational scientific perspective impossible, but at the same time it claims to be authentic.

Apart from these problems - the absence of difference between the researcher and practitioner, invisibility and non-observability of the phenomenon studied, and its claim of authenticity based on UPG - there is one practical but no less significant problem. The willingness of anthropologists to gain relevant data through participation may be limited or blocked by their fear of losing their academic position by appearing irrational, or losing the trust of the subjects when portraying them as irrational and as a consequence making the situation difficult for other anthropologists to come. To put it simply, the uneasy position of the anthropologist studying magic in the academy reflects the uneasy relationship between magic and science.

\section{FOUR PHILOSOPHICAL CONCEPTS OF MAGIC}

Before moving to the four possible ways to deal with magic, I would like to present four main philosophical concepts of magic, elaborated by Josef Veselý in his book Magic (2008 [2001]), which I find very useful. It shows that what practitioners of magic claim to doinfluence or manipulate reality — can be done in four distinct ways. Some of these ways are incompatible with the scientific approach, but some are more compatible and go to meet the anthropological researcher halfway. Needless to say, these approaches rarely occur in their pure form; they are constructs, or conceptual tools to be used in works such as this one. 


\section{THE DEMONOLOGICAL CONCEPT}

As explained by Veselý, the demonological concept of magic is the oldest and at its core is the assumption that the surrounding world is inhabited by real beings such as spirits, demons, and so on. The magician's task is to gain access to this world and make contact with these beings, to learn about them, and to make them into friends or servants. Entry is only possible in altered states of consciousness, such as meditation or trance. The world is ruled by its own laws, so anyone wishing to enter and control the entities and powers inhabiting it must master these laws. Such a connection is not without risks, "as anyone familiar with Dr. Faust's story knows" (Veselý 2008: 21). ${ }^{1}$

This concept was highly regarded during the Renaissance and a number of occultists of the twentieth century grounded their work upon this concept. ${ }^{2}$ It is also characteristic of shamanism.

The demonological concept is incompatible with the scientific approach because it acknowledges the existence of a separate and independent world inaccessible in the everyday state of consciousness. A scholar cherishing objectivity and safe distance and lacking personal experience can do nothing but speak about irrational beliefs and illusions.

\section{ENERGETIC CONCEPT}

This concept is based on the idea of the invisible life force. The teaching of life force in Europe has two different sources. Around 1800, there was the reemergence of the belief that body and soul are not strictly divided and attention turned again to the energies and processes inside human body. The teaching about life force also came to Europe from the East in the form of teaching about chakra and prana. The energetic concept reached its greatest popularity in the 1960s in the English-speaking world due to depth psychology, which spread all around the world after the Second World War (Veselý 2008: 22).

In its purest form (which is rare), the energetic concept does away with spirituality. As expressed by Veselý: "The magician is no longer a conjuror of demons, but rather an artist working with energies" (2008: 22). He or she has to be able to perceive subtle energies, and polarize and direct them. The techniques of working with energies have also been used by magicians working within the demonological concept. They are also embraced by systems where the ritual circle is created within which the practitioners generate and send energy; for example, Wicca. To give another example, the energetic concept is employed by magicians that become involved in magical battles. As my informant explained to me, the winner in these battles is the energetically stronger magician. Technically, this means either sending destructive energy to the enemy (e.g., martial energy) or drawing the energy out of him or her, "eating him out energetically." 3 Needless to say at this point, energy is claimed to be morally neutral; it can be used in both black magic and healing.

1 All quotations originally in Czech are the author's translation.

2 For example, the Czech magician Franz Bardon, the English Hermetic order of the Golden Dawn, and the German order O.T.O. (Ordo Templi Orientis; Veselý 2008: 21).

3 Male, 26 years old, professional artist and independent magician. 
Working with energies is also too intangible for the scientific approach based on objectivity and observation.

\section{PSYCHOLOGICAL CONCEPT}

At the core of this concept is the idea that the spirit is capable of having an effect on the body. The roots of this concept are linked with the names of Sigmund Freud and Carl Gustav Jung. In fact, this concept stands between demonological and energetic. Like the energetic concept, it is homocentric but it works with demons too. The difference is that these demons are not endowed with outer, objective existence, but with an existence that is inner and subjective. In other words, magic is still magic and works on the basis of the same mechanisms-only it is placed inside the human psyche (Veselý 2008: 24).

This concept is based on the assumption that within our psyche there operates a kind of undefined mechanism responsible for achieving desired results in the outer world. Almost all contemporary writers on magic, including anthropologists, use this model. As noted by Veselý, no one really explains why and in what way our subconscious performs these "miracles," but they are taken for granted. In other words, this is a pragmatic approach. It does not aim to explain magic; it only points out to the fact that "manipulation with the psyche yields results" (Veselý 2008: 24).

The advantage of the psychological concept of magic - in the form of speaking about the powers of the subconscious - is that it is much more comprehensible and acceptable for contemporary Western people (including anthropologists) than belief in spirits and demons or "playing" with energies. As such, it stands between rigorous science and magic, and that is why it is frequently employed by anthropologists studying magic. The disadvantage, however, as shall be seen shortly, is that it is merely a compromise. Because it does not really explain magic, such writing is not approved of by rigorous science.

\section{THE INFORMATION CONCEPT}

The core of this concept lies in the idea that "energy acts only through information which in a certain way 'tells' it how to behave" (Veselý 2008: 25). Information is unlimited by time and space because it has no matter or energy. The foundations of "cybermagic" were formulated in the 1980s and developed in a close contact with chaosmagic. ${ }^{4}$

Within this concept, the magician does not need to maintain a good relationship with spirits, have a substantial energetic capacity, know about the "powers of the subconscious," or master the techniques of visualization. All he or she needs is to "master the techniques of raising and transmitting information" (Veselý 2008: 25). As an illustration of the information concept, one can use "sigil magic." Sigil magic claims to be one of "the most effective and economical magical disciplines" (Frater V.D. 2010: 25). Without the need for complicated rituals or magical props, the magician formulates a wish and on the basis

4 For more information, see Peter J. Carrol's Liber Null \& Psychonaut: An Introduction to Chaos Magic (1987). 
of this formulation he or she creates a kind of a seal: the sigil. This sigil then works as a password, as a gate to the entrance. This technique resembles programming languages with addresses of systems and web pages. Both computer icons and sigils lead to the desired goal and only need to be activated by the user or magician. The magician is not familiar with the processes at work between the activation of the sigil and achieving the desired goal. All he or she has to do is to create an appropriate sigil and activate it accurately.

The operations of cyber or information magic are not acts of imagination in the sense of mental magic; they merely deal with information (Veselý 2008: 25). Unsurprisingly, the users of the information concept tend to be the IT experts. There are not many anthropological works dealing with this concept yet.

\section{FOUR SCHOLARLY APPROACHES TO MAGIC}

I decided to include such a lengthy introduction and to present Veselýs philosophical concepts of magic to show the great complexity of magical practice, which is well known in the magical community but not obvious from anthropological articles and books on magic, where the picture of magical practice is often reduced and simplified and based on selected information. The reason is the lack of relevant data because traditional accounts of magic tend to deal with second-hand information about the magical practices of the "others." These are based on the premise that magic is a delusion and will be dealt with in subsection 1 , whereas subsection 2 will deal with more recent research based on participant observation and first-hand data combined with the magic-as-delusion premise.

The accounts of magic that offer a more favorable portrayal of magic, however, are not representative of the ideal way to deal with this uneasy topic; on the contrary, going through their "teething pains," they have to face new limits and problems. Trying to portray magic using scientific means, these approaches tend to be selective in their choice of field. As shall be seen in subsection 4, practitioners of the philosophical concepts of magic incompatible with science are usually ignored. One of the interim solutions to the problem is to not try to solve the problem at all and to deal with magic and science as two authentic but incompatible ways of seeing the world (subsection 3).

The four main scholarly approaches to magic can therefore be divided into two groups. One group is traditionally conceived studies dealing with either second-hand or first-hand information about magical practices, focused on the etic perspective and seeing magic as a delusion. The other two work with first-hand data gained through participation and personal experience; the focus is on the emic perspective and magic is seen as real.

\section{MAGIC AS DELUSION: OBSERVATION WITHOUT PARTICIPATION}

The first approach emphasizes objectivity and the etic perspective. Magic is seen as a delusion and a survival from less-developed times, and as such it is sharply contrasted 
with science and it is believed it will become extinct soon. Instead of participant observation, mere observation or no observation is used. The data gained in this way are distorted and superficial; usually they include a careful description of the reported ritual behavior. If the inner working of magic is described, it usually reflects the preheld theory of the author.

The best-known representative of this approach is the British classical anthropologist James George Frazer (1853-1941). He saw magic as occupying the bottom position of the evolutionary ladder, to be replaced by religion and eventually by "true" science. Needless to say, despite his lack of fieldwork and the bias shared by most scholars working in his time and thinking within the evolutionary paradigm, his understanding of sympathetic magic, especially his description of magic as similar to science, is largely compatible with magic practitioners' view of the matter. ${ }^{5}$

The remnants of this approach can be distinguished in the growing number of theses by students of anthropology and religious studies whose work is a result of desktop study, including sophisticated work with on-line sources, such as web pages of magic groups (those that have them) combined with quantitative research (sending out questionnaires) or limited qualitative research (interviews with a small number of informants). Very rarely do they come to the field and meet their subjects or even participate in a ritual. ${ }^{6}$

The position is also held by anthropologists with interests more tangible than magic. For example, one of my gender-studies colleagues is truly terrified by what (she imagines) I do: "Be careful, these people might try to convert you!" she warned me on one occasion.

The positive aspect of such an approach is the high level of objectivity and clarity. The negatives are the lack of core data and emphasis on the outer (describable) side of magical phenomena. A patronizing tone is typical of such works. The practitioners themselves talk about such authors as about scholars who "do not really understand."

\section{MAGIC AS DELUSION: PARTICIPANT OBSERVATION}

This magic-as-delusion approach is most valued in the academy, despite the risk that their proponents might end up on the black list of the practitioners and the anthropologists that follow them. They win prestige in the academy because they manage to combine the emic and etic perspectives well: to play the role of the insider while remaining an objective outsider. This approach fulfills the ideals of modern anthropological research.

The best-known example of this approach is a widely debated book by the American psychological anthropologist Tanya Luhrmann: Persuasions of the Witch's Craft: Ritual Magic in Contemporary England (1989). Over the span of fourteen months of her fieldwork in London in the 1980s, Luhrmann was initiated into four secret groups, most of them

5 For example, Gareth Knight, a distinguished authority on Western mystery tradition and Qabalistic symbolism, claims that the "mystical is practical religious experience of an inner nature, and magical is practical scientific experience of an inner nature" (Knight 2010 [1975]: 9-10), my italics.

6 One reason is obviously a lack of time. 
Wiccan, and became a member of a great number of others. From the point of view of the amount of fieldwork material collected and the quality of its theoretical background, Luhrmann's book is an impressive and unique ethnography deservedly appreciated in the academy. The problem comes with the formulation of the research question. As described by Luhrmann:

[t]his study looks at ordinary middle-class English people who become immersed in a netherworld of magic and ritual, and asks a classic anthropological question: why do they practice magic when, according to observers, the magic doesn't work? (Luhrmann 1989: 4)

The question is answered by a description of a process of gradual shift from the "normal" to "abnormal," called interpretive drift. When apparently normal (which is supposed to mean middle-class, rational and well-educated) people become involved in magic they start a process of gradually becoming used to abnormality and thus becoming deluded. The idea of interpretive drift presupposes that the magic practitioner comes to magic as a kind of magical tabula rasa, ready to be "reprogrammed" from the scientific paradigm to the magical paradigm. It certainly fits well with Luhrmann's own history (1989: 318-322) and it seems to harmonize, although more loosely, with Luhrmann's informants' stories as she describes them, but it certainly cannot be applied generally. ${ }^{7}$

Another problem common to all academic writing about controversial topics and dealing with people is that it may raise controversial reactions in the people dealt with. Although some practitioners that are knowledgeable of the character of academic writing accepted the book as it was and appreciated its undeniable achievements, ${ }^{8}$ some practitioners Luhrmann came into close contact with felt betrayed by being portrayed in such an unfavorable light and suspicious of any "sympathetic" outsider. For example, the anthropologist Joanne Pearson, when trying to obtain access to magic groups in the 1990s, had to face these kinds of reactions: "you're not going to do another Tanya [Luhrmann] on us are you?" (Evans \& Green 2009).

Research of this type is impossible today, at least in the context of central Europe and particularly the Czech Republic, which I am familiar with. Magical practitioners both organized in covens and as individuals are much more secretive and closed today, and some also tend to be suspicious of anthropologists. Many are simply uninterested in cooperation. Moreover, speaking about traditional Wicca, it is no longer possible to receive training in more than one coven simultaneously, and gaining access to this group or even being accepted for training is lengthy, difficult, and uncertain.

7 For example, the idea of interpretive drift cannot be applied to the life stories of my informants, who were magicians practicing in the Czech Republic at the beginning of the twenty-first century, usually unorganized and whose practice is not based on external knowledge gained at courses (which they rarely attend) but rather on personal gnosis developed since early childhood, combined with reading and magical experiments.

8 Wouter Hanegraaf, professor of the history of hermetic philosophy (personal conversation, 20 March 2012, Nijmegen, Holland). 
When I asked my British informants about this shift, I was told that the 1980s were still early days and the practitioners were open and eager to share some of their beliefs and practices, desiring the approval of mainstream society. Today, after the popularity of magical practice and witchcraft has grown in recent years, the practitioners are much more confident and do not seem to feel the need for approval anymore. The magicians tend to be tolerant, knowledgeable, and friendly people but there are moments when one perceives an air of superiority over the "other people" (including anthropologists) who "do not know."

In the context of contemporary witchcraft and magical practice, as I have come to know it in the Czech Republic and partially in Austria, the performers and researchers have swapped positions. ${ }^{9}$ Being an anthropologist does not open doors; on the contrary, anthropologists must first prove credible and worthy, and in many cases even prove "magical skills" before they are allowed to enter-and even then entry should not be taken for granted. Before they begin their participant observation, anthropologists find themselves in the uncomfortable position of being observed, tested, and evaluated, and very carefully at that.

\section{MAGIC AS REAL: PARTICIPATION}

At the core of this approach, which is rare among anthropologists, is a simple assumption that magic deals with the transcendental and as such it stands beyond the limits of everyday and scientific experience. The representative of this approach is Milan Nakonečný, a Czech professor of psychology, who has published a number of books on magic and hermetism. In his book Magie $v$ historii, teorii a praxi (Magic in Theory, History, and Practice) he claims that "the transcendental cannot become the object of science" (2009: 15) and that the theories formulated by cultural anthropology, for example, drew on a distorted conception of magic (e.g., from the system of superstition $)^{10}$ and do not speak about magic per say, which cannot be squeezed into the scientific (physicalistic) conception of reality.

Reality as conceived by science is based on the imaginary postulate of perceptivity of objects, which is determined by the well-known senses, possibly equipped with devices such as microscopes and telescopes . . . and logical thinking within precisely demarcated concepts determined by scientifically recognized modes and principles such as the principle of causality. ... Reality as conceived by science is only a consensus achieved by means of strict rules about what the outer world looks like. (Nakonečný 2009: 17)

The attempts to explain magic by science are therefore doomed to fail as the magic world transcends the world construed by empirical science (Nakonečný 2009: 16). It is not a mere

9 It is important to point out, however, that I am speaking here about magical activities performed by closed working groups and covens. Obviously it is not a problem in the least to attend public courses or open rituals.

10 By the systems of superstition the magicians practicing "high magic" commonly mean the "low magic" of witches (witchcraft), which they tend to set themselves apart from. 
hallucination, but the world inaccessible by conventional forms of knowing. The magical and scientific view of the world are two distinct cognitive structures that represent two distinct worlds (Nakonečný 2009: 19). In other words, magic and science are like two sides of one coin: one can see one or the other, but not both at the same time.

Nakonečný claims that all attempts by science to penetrate the essence of the magical world using its methods of learning are vain because they were developed to study only the "reality" as construed by science and not the worlds beyond. The only exception is the analytical and depth psychology of Carl Gustav Jung or transpersonal psychology, disciplines whose scientific authority is often questioned by more rigorous sciences (Nakonečný 2009: 18-19).

However much I respect and share this conception of magic, it creates more problems than solutions and it offers no opportunities to the fieldwork anthropologist. Following this logic, an anthropologist wishing to study magic using the common tools of the social sciences is told that it is not possible at all. An anthropologist able to enter the magical world can do so only using means quite unscientific. So the problem remains: how to transmit that knowledge to the scientific and public audience? Is there any bridge to cross the deep chasm between the two visions of the world?

\section{MAGIC AS REAL: PARTICIPANT OBSERVATION}

A number of contemporary anthropologists claim to have found such a bridge, among them the British anthropologist Susan Greenwood, who has published a series of books on the topic: Magic, Witchcraft and the Otherworld (2000), The Nature of Magic (2005), and The Anthropology of Magic (2009). Her method of bridging the gap between the subjective experience of magic and the anthropological observation is to become a translator between these two (as she says) seemingly incompatible and incomprehensible languages (Greenwood 2009: 2).

According to Greenwood, with modernity came the opportunity to study magic from the position of a scientist that is a magical practitioner at the same time. The revival of witchcraft, paganism, and the practice of magic is one of the evident processes of modernity and as such it must be dealt with in a completely novel way: no longer as an activity performed by less developed "others" or our own ancestors in pre-modern times. As expressed by Greenwood herself, "it is now increasingly being employed as a counterpoint to liberal understandings of modernity's rational progress" (2009: 2).

The bridge Greenwood is employing is psychological and she does this by claiming that "magical processes of mind are fuelled through emotion" (Greenwood 2009: 3). To illustrate her point, she summarizes a well-known psychological experiment in which students are asked to stir sugar powder (from a commercially labeled sugar box) into two glasses with clean water and then to attach to one of them the label sucrose and to the other one sodium cyanide-poison. The participants then have very negative feelings toward the glass labeled poison and many are reluctant to drink out of it. There is no logical reason for such 
a feeling. What happens is that an association is created. The word labeling the glass seems to be linked to the nature of the content of the glass (Greenwood 2009: 45). Associative thought stands at the core of sympathetic magic; this "mistaken association of ideas" (as Frazer put it a century ago) as the "fatal flaw of magic" (Frazer 1998: 49) is commonly used by contemporary Western people, Greenwood claims, whether they believe it or not.

Greenwood's strategy is not to explain the inner working of magic, but to show that it "is a universal aspect of human consciousness; it is inherent in the mind ... . Magic is alive" (Greenwood 2009: 4). She follows this statement with the introduction of the term magical consciousness, a term that she uses "to describe a mythopoetic, expanded aspect of awareness that can potentially be experienced by everyone" (Greenwood 2009: 4). By claiming the universality of magic, Greenwood explicitly suggests nothing less than a "transformation of anthropological understanding" of magic. To achieve this goal, she insists that "magic has to be recognized as a legitimate form of knowledge" (Greenwood 2009: 4).

What Greenwood is doing is not trying to persuade readers about the efficacy of magic or explain it, but instead to show them that they have, in fact, always been using magic, and are using magic, but they do not call it magic.

\section{CONCLUSION}

From the examples I used in this paper, it is evident that anthropologists and other scholars avoid explaining magic and, when they do explain it, they do not claim that the explanation is scientific. Writing about it, they can approach it from two basic positions. When they present it as delusion, they can describe its outer form and offer hypotheses of why people mistakenly believe in its efficacy and practice it. In this context, magic is seen as a survival from earlier stages of human evolution and a domain of the less-developed part of the population (Frazer) or of "normal" and rational people (at first sight) that become deluded in the process of getting used to it (Luhrmann). When magic is presented as a real and legitimate way of knowing and seeing the world, it is presented either as distinct from and incompatible with science (Veselý) or as universal to humanity and a feature of modernity describable by psychology (Greenwood).

Using psychology as a tool when dealing with magic is common among those writing about this topic. Obviously, this does not refer to a specific kind of psychology, but to psychology in the most general sense. This unspecified psychology dealing with emotions and processes of the human mind seems to be the best bridge over the gap between these two ways of perceiving and relating oneself to the world and reality. To do that, scholars choose subjects that either themselves work within the framework of the psychological concept of magic or they focus on the part of their practice where they employ this concept. As a result, much has been written about pagans, druids, and contemporary witches and Wiccans as using Jungian psychology. The work of chaos magicians or postmodern 
experimental magicians working within demonological, energetic, and information concepts, which are much less compatible with science, as well as the Wiccan work within these concepts, remain largely unexplored.

Psychology is used by both anthropologists seeing magic as delusion and those seeing it as real. In the first case (and my example), psychology explains the way how apparently rational people may delude themselves and accept as normal that which is abnormal (from the position of mainstream society and the anthropologist) and become irrational believers in magic. In the second case, psychology is used to explain that associative thinking, typical for some kinds of magic, is common to all people, that it is in fact only another way of knowing that everybody uses and should therefore be recognized as legitimate. However, there are still scholars that believe that psychology does not explain anything and that the gap is unbridgeable because magic and science deal with two distinct and independent sections of the world and do not overlap.

To conclude, it is evident that as a consequence of the emergence of the new anthropologist's field, the anthropological paradigm for dealing with magical practice is changing. Or, perhaps better, its homogeneity is dissolving. It is still too early to predict exactly what it will look like in the years to come, but there are hints from both magical and academic circles that a more accurate bridge replacing psychology is in view. Nevertheless, it is still valid, and it is my personal direction too, to proceed in the study of contemporary magical practice from the position suggested by E. E. Evans-Pritchard in his famous study of the Azande. This position is based on the idea that there is no universally valid matrix for consideration of the validity or "truth" of what people do. Human actions and practices are seen as meaningful and "true" in their contexts: scientific ones in the context of science, and magical in the context of magic. From this point of view, the above categorization based on the belief in the efficacy of magic seems irrelevant, the change in the anthropological field only minor, and the positions of Luhrmann and Nakonečný compatible. After all, magic is not about belief but about practice. The anthropologist's task is not to explain magic, but to show how this practice makes sense in the given context, be it a context of a traditional magic-appreciating society or a context of contemporary practitioners in Europe.

\section{REFERENCES}

Barnard, Alan, \& Spencer, Jonathan (eds.)

2004 Encyclopedia of Social and Cultural Anthropology. London: Routledge.

Evans, Dave, \& Green, Dave (eds.)

2009 Ten Years of the Triumph of the Moon. Hidden Publishing.

Frater V.D.

2010 Praktická sigilická magie. Prague: Nakladatelství Vodnář.

Frazer, James George

1998 [1922] The Golden Bough. Oxford: Oxford University Press. 
Greenwood, Susan

2009 The Anthropology of Magic. Oxford: Berg.

Knight, Gareth

2010 [1975] Experience of the Inner Worlds. Cheltenham: Skylight Press.

Luhrmann, Tanya M.

1989 Persuasions of the Witch's Craft: Ritual Magic in Contemporary England. Cambridge: Harvard University Press.

Nakonečný, Milan

2009 [1999] Magie v historii, teorii a praxi. Prague: Nakladatelství Vodnáŕ.

Veselý, Josef

2008 Magie. Prague: Nakladatelství Vodnár.

\section{IZVAJALCI IN RAZISKOVALCI V KONTEKSTU NOVEGA POGANSTVA}

Vnovopoganskih in magičnih okoljih ni več tradicionalne razlike med antropologom in "drugimi", saj imajo raziskovalci in izvajalci pogosto podobno etnično ozadje, družbeno pozicijo in stopnjo formalne izobrazbe. Zato se pojavi nov problem: kako ravnati in razumeti tako prakticiranje magije kot tudi druge aktivnosti, ki pomenijo središč življenja mnogim sodobnim poganom, torej prakse, ki so jih tradicionalno dojemali in obravnavali kot iluzije. Avtorica je izpostavila dve osnovni dojemanji, ki ju antropologi zavzemajo ob stiku z magijo: pasivno, z opazovanjem $z$ udeležbo, ali aktivno, s sodelovanjem lahko prakse obravnavajo kot iluzije ali razumejo in predstavljajo kot resnične. Ob iskanju odgovora na vprašanje o magičnih praksah avtorica poudarja, da v teh primerih ne gre toliko za verovanje kot za prakse same. Antropologova naloga ni razložiti magijo, temveč razumeti, kako so te prakse smiselne $v$ določenem kontekstu, naj gre za družbo, ki take prakse spoštuje, ali za skupine sodobnih izvajalcev v Evropi in Ameriki.

Dr. Kamila Velkoborská, University of West Bohemia, Faculty Philosophy and Arts, Katedra anglického jazyka a literatury, Sedláčkova 15, 30614 Plzeň, camilla@kaj.zcu.cz 